\title{
Nitrogen addition mediates the effect of soil microbial diversity on microbial carbon use efficiency under long-term tillage practices
}

\author{
Mengni Zhang ${ }^{1}$, Shengping Li $^{1}$, Xueping $\mathrm{Wu}^{1}$, Fengjun Zheng ${ }^{1}$, Xiaojun Song ${ }^{1}$, Jinjing \\ $\mathrm{Lu}^{1}$, Xiaotong Liu ${ }^{1}$, Bisheng Wang ${ }^{2}$, Ahmed Abdelrhman ${ }^{1}$, and Aurore Degree ${ }^{3}$ \\ ${ }^{1}$ Chinese Academy of Agricultural Sciences Institute of Agricultural Resources and \\ Regional Planning \\ ${ }^{2}$ Qingdao Agricultural University \\ ${ }^{3}$ University of Liege Faculty of Gembloux Agro-Bio Tech
}

January 22, 2022

\begin{abstract}
Tillage practices can influence soil microbial carbon use efficiency (CUE), which is critical for carbon cycling in terrestrial ecosystems. The effect of tillage practices could also be regulated by nitrogen (N) addition. However, the soil microbial mechanism about $\mathrm{N}$ fertilizer effect on microbial CUE under no-tillage is still unclear. We investigated how $\mathrm{N}$ fertilizer regulates the effect of tillage management on microbial CUE through changing microbial properties and further assessed the impact of microbial CUE on particulate (POC) and mineral-associated organic matter carbon (MAOC) using a 16-yr field experiment with no-tillage (NT) and conventional tillage (CT), both of which combined with $105(\mathrm{~N} 1), 180(\mathrm{~N} 2)$, and $210 \mathrm{~kg} \mathrm{~N}^{-1}$ (N3) N application. We found that microbial CUE increased with increasing $\mathrm{N}$ application rate. NT increased microbial CUE compared with CT under N1. The bacterial and fungal diversities of NT was higher than CT and N application decreased their diversities in the $0-10 \mathrm{~cm}$ layer. The partial least squares path model showed that bacteria diversity, fungal diversity, and fungal community structure played more critical roles in increasing microbial CUE. Furthermore, POC and MAOC under NT were higher than $\mathrm{CT}$ and they also increased with increasing $\mathrm{N}$ application rate. This could be explained by the finding that increasing microbial CUE induced by $\mathrm{N}$ application had the potential to increase POC and MAOC. Overall, $\mathrm{N}$ addition is an important pathway to influence microbial CUE, which is mainly regulated by bacterial and fungal diversities rather than their biomass under no-tillage.
\end{abstract}

Nitrogen addition mediates the effect of soil microbial diversity on microbial carbon use efficiency under long-term tillage practices

Mengni Zhang a, b, Shengping $\mathrm{Li}^{\text {a, }}{ }^{*}$, Xueping Wu ${ }^{\text {a, c, * }}$, Fengjun Zhenga ${ }^{\mathrm{a}}$, Xiaojun Song ${ }^{\mathrm{a}}$, Jinjing Lu ${ }^{\mathrm{a}, \mathrm{b}}$, Xiaotong Liu ${ }^{a}$, Bisheng Wang ${ }^{\mathrm{d}}$, Ahmed Ali Abdelrhmana ${ }^{\mathrm{a}}$, Aurore Degré ${ }^{\mathrm{b}}$

${ }^{a}$ Institute of Agricultural Resources and Regional Planning, Chinese Academy of Agricultural Sciences, Beijing 100081, PR China

${ }^{b}$ University of Liege, GxABT, Terra Research Center, 2 Passage des Déportés, 5030, Gembloux, Belgium

${ }^{c}$ Ministerial and Provincial Co-Innovation Centre for Endemic Crops Production with High-quality and Efficiency in Loess Plateau, Taigu 030801, China

${ }^{d}$ College of Agronomy Qingdao Agricultural University, Qingdao 266109, China

Corresponding authors:

${ }^{1}$ Shengping Li 
E-mail address:lishengping@caas.cn

${ }^{2}$ Xueping $\mathrm{Wu}$

E-mail address:wuxueping@caas.cn

Institute of Agricultural Resources and Regional Planning, Chinese Academy of Agricultural Sciences

No. 12 Zhongguancun South Street, Haidian District, Beijing 100081, PR China

Tel./fax: +86-10-82108665

\begin{abstract}
Tillage practices can influence soil microbial carbon use efficiency (CUE), which is critical for carbon cycling in terrestrial ecosystems. The effect of tillage practices could also be regulated by nitrogen $(\mathrm{N})$ addition. However, the soil microbial mechanism about $\mathrm{N}$ fertilizer effect on microbial CUE under no-tillage is still unclear. We investigated how $\mathrm{N}$ fertilizer regulates the effect of tillage management on microbial CUE through changing microbial properties and further assessed the impact of microbial CUE on particulate (POC) and mineral-associated organic matter carbon (MAOC) using a 16-yr field experiment with no-tillage (NT) and conventional tillage (CT), both of which combined with 105 (N1), 180 (N2), and $210 \mathrm{~kg} \mathrm{~N} \mathrm{ha-1}$ (N3) N application. We found that microbial CUE increased with increasing $\mathrm{N}$ application rate. NT increased microbial CUE compared with CT under N1. The bacterial and fungal diversities of NT was higher than $\mathrm{CT}$ and $\mathrm{N}$ application decreased their diversities in the 0-10 $\mathrm{cm}$ layer. The partial least squares path model showed that bacteria diversity, fungal diversity, and fungal community structure played more critical roles in increasing microbial CUE. Furthermore, POC and MAOC under NT were higher than CT and they also increased with increasing $\mathrm{N}$ application rate. This could be explained by the finding that increasing microbial CUE induced by $\mathrm{N}$ application had the potential to increase POC and MAOC. Overall, $\mathrm{N}$ addition is an important pathway to influence microbial CUE, which is mainly regulated by bacterial and fungal diversities rather than their biomass under no-tillage.
\end{abstract}

\title{
Keywords
}

Microbial community; Microbial carbon use efficiency; Nitrogen; No-tillage; Soil organic carbon

\section{Introduction}

Soil biodiversity loss induced by agricultural practices threatened the provision of soil ecosystem functions (De valença et al. , 2017; Huang et al. , 2019). One of the functions is soil organic carbon (SOC) storage (Chen et al. , 2017; Novara et al. , 2017), which is crucial to the determination of carbon (C) cycling in ecological systems. The $\mathrm{C}$ stock is susceptible to microbial carbon use efficiency (CUE) that is the fraction of $\mathrm{C}$ taken up by microbial cells and retained in biomass as opposed to being respired (Li et al., 2019; Li et al., 2014; Zhou et al., 2020). Furthermore, tillage practices could influence soil microbial CUE by changing some soil properties (e.g., temperature and moisture) (Domeignoz-Hortaet al. , 2020; Manzoni et al. , 2012). Soil microbial CUE can also be regulated by nitrogen (N) addition (Kallenbach et al. , 2019; Widdig et al. , 2020). Previous studies further found that microbial community structure and compositions are critical factors influencing microbial CUE (Nunes et al. , 2020; Sinsabaughet al. , 2016; Wang et al. , 2020). Therefore, it is essential to study the soil microbial mechanism responsible for the effect of $\mathrm{N}$ application on microbial CUE to better understanding carbon sequestration under tillage management.

No-tillage is one of the main conservation tillage practices and numerous studies have investigated its effect on microbial CUE (Kallenbach et al. , 2019; Mo et al., 2021; Yang et al. , 2020a). Some studies have shown that no-tillage increased microbial CUE compared with conventional tillage (Kallenbach et al. , 2019; Mo et al. , 2021; Sauvadet et al. , 2018), but no effect was also found (Van Groenigen et al. , 2013). A possible reason for the different effects is that $\mathrm{N}$ application could influence microbial CUE (Kallenbach et al. , 2019; Mo et al. , 2021; Van Groenigen et al. , 2013) and its application rate is different among these studies. N application can also affect microbial growth and respiration by changing soil nutrient availability, particularly 
for $\mathrm{N}$, because decomposer cells need to maintain balanced compositions of $\mathrm{C}$ and $\mathrm{N}$ (Manzoni et al. , 2012). In addition, the limitation of $\mathrm{N}$ increases over-flow respiration or $\mathrm{C}$ excretion rather than microbial growth, which further decreases microbial CUE (Qiao et al. ,2019). Previous studies showed that no-tillage with straw retention could decrease soil $\mathrm{N}$ availability (Gentile et al. , 2011; Thierfelder et al. , 2018). These findings indicate that $\mathrm{N}$ application is a promising way to induce no-tillage systems to increase microbial CUE.

Microbial CUE can be influenced by microbial populations that have different rates of organic matter decomposition and absorption (Waldrop \& Firestone, 2004). Adu and Oades (1978) found that fungi played a more important role than bacteria on microbial CUE. The main reason is that the C:N variation range of fungi is generally wider than that of bacteria and fungi have a higher demand for $\mathrm{C}$ element than bacteria (Keiblinger et al. , 2010). However, other studies showed no significant difference in the effect of microbial CUE induced by fungi and bacteria (Six et al. , 2006; Thiet et al. , 2006). One reason for these conflicting results is that $\mathrm{N}$ application could also influence microbial CUE by stimulating microbial activity and decreasing microbial respiration metabolism (Lee \& Schmidt, 2014; Liu et al. , 2018; Thiet et al. , 2006) and the difference $\mathrm{N}$ application rates under these studies could contribute to the discrepancy. Another reason is that these studies only focused on the influence of microbial populations and biomass on microbial CUE (Keiblinger et al. , 2010; Waldrop \& Firestone, 2004) and ignore the key role of microbial diversity on microbial CUE (Domeignoz-Horta et al. , 2020). Hence, studying the impact of $\mathrm{N}$ application on microbial CUE based on its effects on microbial diversity and community structure could provide a comprehensive perspective to reveal the effect of $\mathrm{N}$ addition on $\mathrm{C}$ cycling.

Furthermore, the increase of microbial CUE is an effective means of increasing SOC sequestration (Bradford et al. , 2013; Haddixet al. , 2016). SOC fractions, especially for particulate organic matter carbon (POC) and mineral-associated organic matter carbon (MAOC), are more sensitive to microbial CUE than total SOC (Averill \& Waring, 2018; Chenet al. , 2018; Ye et al. , 2018). Averill and Waring (2018) found that substrate use efficiency can also directly affect $\mathrm{C}$ cycling through changing POC and MAOC. In addition, $\mathrm{N}$ addition significantly influenced on soil POC and MAOC (Chenet al. ,2020b, 2019; Ye et al. , 2018). However, it remains unclear how $\mathrm{N}$ application regulates the effect of soil microbial CUE on POC and MAOC under tillage management. Therefore, studying the effects of $\mathrm{N}$ application is essential to understanding the role of soil microbial CUE on carbon sequestration potential.

This study was conducted to investigate the influence of $\mathrm{N}$ application on microbial CUE under tillage practices from a microbiological perspective. We hypothesized that: (i) the responses of soil microbial diversity, community structure, biomass, and CUE to N application under CT and NT were different, and (ii) microbial diversity plays a more important role than microbial biomass in microbial CUE. The objectives of this study were to (i) evaluate the effects of tillage management and $\mathrm{N}$ application on soil microbial diversity, community compositions, and soil microbial CUE, (ii) reveal how $\mathrm{N}$ application influences soil microbial CUE by regulating microbial diversity, community structure, and biomass, and (iii) assess the influence of microbial CUE on soil POC and MAOC under tillage management with different $\mathrm{N}$ application rates.

\section{Materials and methods}

\subsection{Study site}

We conducted a continuous field experiment from 2003 to 2019 at a Dryland Farming Experimental Station in Shouyang $\left(112-113^{\circ} \mathrm{E}, 37-38^{\circ} \mathrm{N}\right)$, Shanxi Province in northern China. The climate of the station is continental monsoon and its average annual potential precipitation and evaporation is $484 \mathrm{~mm}$ and $1750 \mathrm{~mm}$, respectively (Wang et al. , 2019). The annual frost-free season lasts on average 131 days. The sandy loam cinnamon soil in experimental site was classified as Calcaric-Fluvic Cambisols (Li et al. , 2020). Table 1 shows soil chemical and physical properties initially.

\subsection{Experimental design}

The long-term experiment was set up in 2003 using a randomized complete block design with three replicates. 
Each plot size was $5 \mathrm{~m} \times 5 \mathrm{~m}$, the crop was continuous spring maize and there was a fallow period from November to March.

Three $\mathrm{N}$ fertilizer rates were applied under two tillage treatments in this study and the two tillage practices were CT (conventional tillage with maize stalk removed after harvesting, plowed twice to about $25 \mathrm{~cm}$ depth using moldboard plow after harvesting and before seeding, and fertilized before plow in April) and NT (notillage with the maize stalk mulched after harvesting, then seeded with a no-till planter and $\mathrm{N}$ fertilizer were applied in small holes between two maize in each row in April). The three $\mathrm{N}$ fertilizer rates were N1 (105 kg $\left.\mathrm{N} \mathrm{ha}^{-1}\right), \mathrm{N} 2\left(180 \mathrm{~kg} \mathrm{~N} \mathrm{ha}^{-1}\right)$, and N3 $\left(210 \mathrm{~kg} \mathrm{~N} \mathrm{ha}^{-1}\right)$ using urea. The row and plant spacings were 60 and $30 \mathrm{~cm}$, respectively.

\subsection{Soil sampling}

We collected soil samples from depths of $0-10 \mathrm{~cm}$ and $10-25 \mathrm{~cm}$ using a $10 \mathrm{~cm}$ diameter soil auger on 1 August 2019. The sampling date corresponded to the tasseling stage. The soil samples were stored in airtight polypropylene bags and placed in a cool box at $4^{\circ} \mathrm{C}$ during transportation to the laboratory. Litter, roots, and gravel in soil samples were removed and the soil was divided into several samples for further analyses.

\subsection{Soil analysis}

\subsection{1 biochemical analysis}

We assessed the soil microbial biomass carbon (MBC) and nitrogen (MBN) by the chloroform fumigation extraction method (Cleveland \& Liptzin, 2007). Fresh soil samples transported in an ice-cooled box were separated into two aliquots ( $15 \mathrm{~g}$ on a dry weight basis). One set of soil subsamples was extracted using 0.5 $\mathrm{M} \mathrm{K}_{2} \mathrm{SO}_{4}$ to measure the $\mathrm{MBC}$ and $\mathrm{MBN}$. Organic $\mathrm{C}$ in the $\mathrm{K}_{2} \mathrm{SO}_{4}$ extracted solution was analyzed using a TOC analyzer (Vario TOC, Elementar, Germany). Both MBC and MBN concentrations were corrected for unrecovered biomass using a $\mathrm{k}$ factor of 0.45 (Jenkinson et al. , 2004).

Microplate-scale fluorometric procedures were employed to assay the activity of the following hydrolases (Sinsabaugh et al. , 1997): $\beta$-1, 4-glucosidase (BG), $\beta-1,4$-N-acetyl-glucosaminidase (NAG), and leucine aminopeptidase (LAP). We prepared substrates and buffer solutions in sterile deionized water. In this study, $1 \mathrm{~g}$ of fresh soil sample was homogenized in $125 \mathrm{~mL} 50 \mathrm{mM}$ sodium acetate buffer. The $50 \mu \mathrm{l}$ of $50 \mathrm{mM}$ buffer was dispensed into 16 replicate sample wells (sample solution + substrate), eight blank wells (sample solution + buffer), eight reference standard wells (buffer + standard), and eight negative control wells (buffer + substrate). The prepared microplates were then placed in a dark microcosm for $4 \mathrm{~h}$ at $20{ }^{\circ} \mathrm{C}$. Finally, the reaction was stopped by adding $1 \mu \mathrm{l}$ of $1 \mathrm{M} \mathrm{NaOH}$ to each well. The fluorescence was measured using an automated fluorometer (BioTek Synergy H1 microplate reader, Winooski, VT, USA) with an excitation wavelength of $365 \mathrm{~nm}$ and an emission wavelength of $450 \mathrm{~nm}$. After correction of the assay wells' fluorescence measurements for the negative controls, blanks, and quench standard wells, the enzymatic activities were expressed as nanomoles of substrate released per hour per gram of dry soil (Saiya-Cork et al. , 2002).

\subsubsection{Ecoenzymatic stoichiometry and CUE estimation}

We used the activities of the enzymes, the $\mathrm{C}$ and $\mathrm{N}$ contents of the soil microbial biomass, and labile organic matter to calculate the CUE according to the previous studies (Geyer et al. , 2019; Sinsabaugh et al. , 2016; Sinsabaugh \& Shah, 2012). The labile nutrient content was also replaced with soil organic matter (Sinsabaugh et al. , 2016)(Zhou et al. , 2020). Previous study also found that the CUE calculated from stoichiometric models was similar to it according to direct measurements of bacterial and fungal growth and respiration (Sinsabaugh et al. , 2016).

The microbial carbon use efficiency was calculated using the following equation:

$C U E_{C: N}=C U E_{M A X}\left[S_{C: N} /\left(S_{C: N}+k_{N}\right)\right](1)$

where $S_{C: N}=\left(1 / E E A_{C: N}\right)\left(B_{C: N} / L_{C: N}\right), \mathrm{S}_{\mathrm{C}: N}$ is a scalar that reflects the ability of the microorganisms to adjust the imbalance between the elemental composition of the available resources and the composition of the 
microbial biomass through the allocation of enzymatic activities. $\mathrm{K}_{\mathrm{N}}$ is the half-saturation constant with a value of 0.5 . Based on the thermodynamic constraints, $\mathrm{CUE}_{\max }$ is assumed to be 0.6 for the highest microbial growth efficiency. $\mathrm{EEA}_{\mathrm{C}: \mathrm{N}}$ is the ratio of the C-acquiring activity to the $\mathrm{N}$-acquiring activity, $E E A_{C: N}=B G$ $/(N A G+L A P) . \mathrm{B}_{\mathrm{C}: \mathrm{N}}$ represents the molar ratio of $\mathrm{C}$ to $\mathrm{N}$ of the soil microbial biomass. $\mathrm{L}_{\mathrm{C}: \mathrm{N}}$ represents the molar ratio of SOC to TN for the soil substrate that is consumed.

The threshold element ratios (TER) for C:N were estimated by the following function:

$T E R_{C: N}=L_{C: N} \times E E A_{C: N}(2)$

where $\mathrm{L}_{\mathrm{C}: \mathrm{N}}$ and $\mathrm{EEA}_{\mathrm{C}: \mathrm{N}}$ have the same meanings as in Eq. (1).

2.4.3 PLFA analysis

Total microbial biomass and microbial community structure were assessed using phospholipid fatty acid (PLFA) analysis. We used a modified Bligh and Dyer method to extract PLFAs (Börjesson et al. , 1998). Total lipids were extracted overnight from $5 \mathrm{~g}$ freeze-dried soil in a solvent phase of $3.0 \mathrm{ml} 50 \mathrm{mM}$ phosphate buffer $(\mathrm{pH}=7.0), 3.8 \mathrm{ml}$ chloroform, $7.6 \mathrm{ml}$ methanol, and $4 \mathrm{ml}$ Bligh and Dyer reagent (chloroform/methanol/phosphate buffer $(1: 2: 0.8, \mathrm{v} / \mathrm{v} / \mathrm{v}))$. The extracted lipids were subsequently added to Discovery@ DSC-Si SPE Tubes (Sigma-Aldrich), then separated into neutral lipids, glycolipid, and phospholipid by sequential addition of chloroform, acetone, and methanol solutions. We added PLFA 19:0 (Larodan Malmö, Sweden) to the phospholipid fraction as an internal standard. PLFAs were transesterified to fatty acid methyl esters using $1 \mathrm{ml} 0.2 \mathrm{M}$ methanolic-KOH (Chowdhury \& Dick, 2012). We analyzed the extracts using a gas chromatograph equipped with a flame-ionization detector (Agilent 6890, Agilent Technologies,

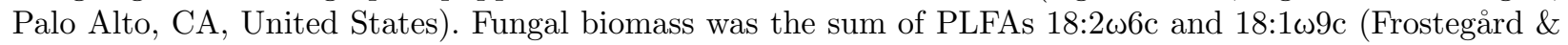
Bååth, 1996; White et al. , 1996). PLFAs a15:0, a17:0, i14:0, i15:0, i16:0, i17:0 were used as markers for

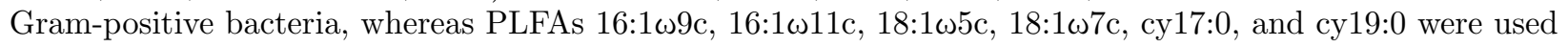
as markers for Gram-negative bacteria (Brockett et al. , 2012; Frostegård \& Bååth, 1996). Actinomycetes biomass was calculated based on the fatty acid: 10Me16:0 and 10Me18:0 (Willers et al. , 2015). Total bacterial biomass was the sum of $\mathrm{G}^{+}, \mathrm{G}^{-}$, and Actinomycetes biomass. We further calculated the ratio of fungal to bacterial biomass (F: B ratio) in soil samples using PLFAs data.

\subsubsection{DNA extraction}

Five grams aliquots of soil samples were mixed with $25 \mathrm{~mL} 0.1 \mathrm{~mol} / \mathrm{L}$ Tris- $\mathrm{HCl}(\mathrm{pH} 8.0)$, shaken and filtered through three layers of sterile gauze. The filtrate was then centrifuged at $10000 \times g$ for 20 min at $4{ }^{\circ} \mathrm{C}$. DNA was subsequently extracted from the pellets using a GMO food DNA Extraction Kit (Illumina MiSeq 250 PE, Auwigene Company, Beijing, China) according to the manufacturer's protocols. The total DNA concentration and quality were checked using a spectrophotometer (NanoDrop, ND2000, ThermoScientific, United States) and agarose gel electrophoresis.

\subsubsection{S rRNA gene amplicon sequencing and ITS amplicon sequencing}

Variable regions V3-V4 on microbial 16S rRNA gene of bacteria and the ITS2 region of fungi were amplified using PCR $\left(95{ }^{\circ} \mathrm{C}\right.$ for $3 \mathrm{~min}$, followed by 30 cycles at $98{ }^{\circ} \mathrm{C}$ for $20 \mathrm{~s}, 58{ }^{\circ} \mathrm{C}$ for $15 \mathrm{~s}, 72{ }^{\circ} \mathrm{C}$ for $20 \mathrm{~s}$ and a final extension at $72{ }^{\circ} \mathrm{C}$ for $5 \mathrm{~min}$ ). The microbial $16 \mathrm{~S}$ rRNA gene was amplified by forwarding primer $338 \mathrm{~F}$ (5'-ACTCCTACGGGAGGCAGCAG-3') and reverse primer 806R (5'- GGACTACVVGGGTATCTAATC 3') (Lee et al. , 1993). The ITS was amplified with the following forward/reverse primer set: ITS1F/ITS2R (CTTGGTCATTTAG AGGAAGTAA/GCTG-CGTTCTTCATCGATGC) (Luanet al. , 2015). PCR reactions were performed in $30 \mu \mathrm{L}$ mixture containing $15 \mu \mathrm{L}$ of $2 \times$ KAPA Library Amplification ReadyMix, $1 \mu \mathrm{L}$ of each primer $(10 \mu \mathrm{mol} / \mathrm{L}), 10 \mathrm{ng}$ of template DNA, and $\mathrm{dd}_{2} \mathrm{O}$. The PCR products were detected using 1\% agarose gel electrophoresis, then purified with an AxyPrep DNA gel Extraction Kit (Axygen Biosciences, Union City, CA, United States). Amplicon libraries were quantified using a Fluorometer (Applied Biosystems 7500, Thermo Fisher Scientific, United States), after which amplicons were sequenced (Illumina MiSeq PE250, Allwegene Technologies, China). 


\subsubsection{Soil fractions separation}

We used the soil wet-sieving method to separate different soil fractions (Curtin et al. , 2019; Fang et al. , 2019). To separate soil organic matter into labile and stable $C$ fractions, we conducted a combined density and particle size fractionation (Herath et al. , 2014; Six et al. , 1998). The physical fractionation to separate two soil $\mathrm{C}$ fractions: light fraction, defined as f-POM, and the heavy fraction that contained aggregate protected organic matter (o-POM, $>53 \mu \mathrm{m}$ fraction) and mineral protected organic matter $(\mathrm{MAOM}<53$ $\mu \mathrm{m}$ fraction) (Fanget al. , 2019). Density fractionation of the soils was then performed to isolate light fraction and heavy fraction using sodium polytungstate (SPT, IMBROS, Australia) (Herath et al. , 2014; Sixet al. , 1998).

All fractions were dried $\left(60{ }^{\circ} \mathrm{C}\right)$ and weighed to obtain the mass proportion of each fraction relative to the bulk soil. The soil fractions were ground to $<53 \mu \mathrm{m}$ for $\mathrm{C} \%$ analyses. Samples were then acidified with 1.0 $\mathrm{M} \mathrm{HCl}$ to decompose the carbonate, after which they were dried for 8 hours at 60 . After drying, the samples were ground $(<0.149 \mathrm{~mm})$ with a mortar and pestle and the SOC was measured by dry combustion method using an elemental analyzer (Vario Macro C/N, Elementar, Germany).

\section{Statistics}

The data were analyzed by three-way ANOVA to compare the effects of soil depth, tillage management, nitrogen application rates, and their interaction on enzyme activities, microbial CUE, PLFAs, and microbial diversity. We compared the means by using the least significant difference with a significance level of $\mathrm{P}$ $<0.05$. Statistical analyses were performed using the SPSS 18.0 software (SPSS Inc., Chicago, United States). Sequences were processed using Quantitative Insights Into Microbial Ecology (QIIME) version 1.9.1 (Caporaso, 2010). Operational taxonomic units clustering at $97 \%$ of identity were collected using UCLUST in QIIME software. Changes in the microbial community structures of the soil samples were evaluated by principal coordinate analysis $(\mathrm{PCoA})$ in $\mathrm{R}$ (v. 3.4.1). The relationships among agricultural practices, soil microbial diversity and community structure, microbial biomass, soil microbial CUE, and soil POC were explored by using partial least squares path modeling (PLS-PM). Estimates of path coefficients and coefficients of determination $\left(\mathrm{R}^{2}\right)$ in our path model were validated by $\mathrm{R}$ (v.3.4.1) with the 'plspm' package (Ai et al. , 2018). The model was assessed using the Goodness of Fit (GoF) statistic, where the GoF value was set to 0.69 .

\section{Results}

\subsection{Changes in enzyme activities and microbial $C U E_{C: N}$}

NT significantly increased BG and NAG activities on average relative to CT (Fig. 1). BG and NAG activities decreased with soil depth under NT, whereas soil depth had no influence under CT. Moreover, both variables of N2 was higher than N1 and N3. Compared with N2, N1 and N3 significantly decreased BG and NAG activities at $0-10 \mathrm{~cm}$ and $10-25 \mathrm{~cm}$ depths (Fig. 1). Moreover, the average value of LAP activity under CT treatment was higher than that of NT (Fig. 1c-d) and it was higher under N2 than under N1 and N3 for CT treatment.

The average value of $\mathrm{CUE}_{\mathrm{C}: \mathrm{N}}$ under $\mathrm{CT}$ was increased by $16.2 \%$ compared with NT and soil depth did not influence it under the two tillage practices (Fig. $2 \mathrm{~g}-\mathrm{h}$ ). The value of $\mathrm{CUE}_{\mathrm{C}: \mathrm{N}}$ increased with increasing $\mathrm{N}$ application. $\mathrm{NT}$ increased the $\mathrm{CUE}_{\mathrm{C}: \mathrm{N}}$ compared with $\mathrm{CT}$ in the $0-10 \mathrm{~cm}$ and $10-25 \mathrm{~cm}$ layers under N1, whereas there was no significant difference between NT and CT under N3. These results showed that increasing $\mathrm{N}$ application rates under $\mathrm{NT}$ could enhance $\mathrm{CUE}_{\mathrm{C}: \mathrm{N}}$.

\subsection{Soil microbial community}

The PLFA contents of the total and grouped soil microorganisms under tillage and $\mathrm{N}$ application treatments are shown in Fig. 3. All of the PLFA contents in the 0-10 cm layer were greater than in the $10-25 \mathrm{~cm}$ layer under NT, but the total PLFAs and bacterial PLFAs did not change with soil depth under CT. The average values of bacteria, fungi, and actinomycetes PLFAs were higher under NT than CT. In addition, 
only fungi and the F:B ratio were significantly affected by N level (Table S3). Overall, the total PLFAs were increased by $19.2 \%$ under NT compared with CT and not significantly affected by N level (Fig. 3a-b). For each grouped soil microorganism, bacterial PLFAs and actinomycetes PLFAs under NT were increased by $21.2 \%$ and $24.4 \%$, respectively, compared with $\mathrm{CT}$, but not significantly affected by $\mathrm{N}$ level at both depths (Fig. 3c-d and Fig. 3g-h). Fungal PLFAs also increased under NT compared with under CT. The fungal PLFAs of N2 was the highest than N1 and N3 under NT, while there was no effect of N application rate under $\mathrm{CT}$ in the $0-10 \mathrm{~cm}$ layer (Fig. 3e-f). Moreover, the $\mathrm{G}^{+}: \mathrm{G}^{-}$ratio was insignificantly affected by soil depth, tillage treatments, and $\mathrm{N}$ application rates (Table $\mathrm{S} 3$ ). The $\mathrm{G}^{+}: \mathrm{G}^{-}$ratio increased with increasing $\mathrm{N}$ application rates under $\mathrm{NT}$ and there was no effect of $\mathrm{N}$ application rate under $\mathrm{CT}$ at $0-10 \mathrm{~cm}$ (Fig. $3 \mathrm{i}-\mathrm{j}$ ). In addition, the $\mathrm{F}: \mathrm{B}$ ratio was not significantly affected by tillage management. N2 produced a higher $\mathrm{F}: \mathrm{B}$ ratio than the other two $\mathrm{N}$ levels under $\mathrm{NT}$, whereas there was no effect of $\mathrm{N}$ application rate on $\mathrm{F}: \mathrm{B}$ ratio under CT in both depths (Fig. 3k-l).

\subsection{Soil bacteria community compositions}

According to $16 \mathrm{~S}$ rRNA gene sequences, the number of sequences per sample ranged from 31458 to 172704 at a $97 \%$ sequence identity threshold. Overall, a total of 8232 OTUs were identified. Actinobacteria $(14.5 \%-$ $32.6 \%$ relative abundance), Proteobacteria (16.5\%-28.7\% relative abundance), Acidobacteria (15.5\%-37.1\% relative abundance), Chloroflexi (10.5\%-21.6\% relative abundance), and Gemmatimonadetes (4.0\%-6.9\% relative abundance) were considered the dominant phyla associated with residue decomposition (Fig. 4a-b). These five phyla accounted for $96.4 \%$ of all sequence reads (Fig. 4).

$\mathrm{N}$ application, tillage $\times$ soil depth, and $\mathrm{N} \times$ tillage interaction significantly influenced the bacterial (16S) community compositions (Table S4). For the dominant phyla, the relative abundances of Acidobacteria, Planctomycetes, and Firmicutes increased with soil depth, while the relative abundances of Proteobacteria, Actinobacteria, Bacteroidetes, and Verrucomicrobia declined with soil depth (Fig. 4). Compared with CT, NT increased the relative abundances of Proteobacteria and Bacteroidetes in the $0-25 \mathrm{~cm}$ layer. The relative abundances of Bacteroidetes increased with an increasing in $\mathrm{N}$ application under NT, while $\mathrm{N}$ application

had no effect on them under CT. Tillage management also had no influence on the relative abundances of Chloroflexi. Furthermore, N2 increased the relative abundances of Chloroflexi compared with N1 and N3 under CT, whereas the relative abundances of Chloroflexi of N1 were higher than N2 and N3 under NT in both layers.

\subsection{Soil fungi community composition}

Fungi were clustered at the phylum level. The histogram of community structure constructed according to OTU sequence abundance after clustering (Fig. 4c-d) revealed structural and abundance differences among $\mathrm{N}$ application rates and tillage treatments. There were five phyla of eumycota with an abundance $>0.01 \%$ in these treatments. Ascomycota and Mortierellomycota were the two most dominant, accounting for $>60 \%$ of all phyla.

$\mathrm{N}$ application, tillage, and soil depth significantly affected the fungal ITS community composition (Table S5). The abundance of Basidiomycota was higher under NT than under CT and showed a trend of first decreasing, then increasing with increasing $\mathrm{N}$ application rates under NT. We also found that the relative abundance of Mortierellomycota was higher under CT than NT in both layers.

\subsection{Diversity of soil bacteria and fungi}

NT significantly increased soil bacterial diversity on average compared with CT (Fig. 5). Its diversity decreased with soil depth under NT. N application also significantly affected bacterial diversity under NT, whereas $\mathrm{N}$ application and soil depth had no effect under CT. NT had higher bacterial diversity than CT in the 0-10 $\mathrm{cm}$ layer. Bacterial diversity decreased with an increase in N application rates under NT in the 0-10 cm layer, while N application had no influence in the 10-25 cm layer. Similarly, NT significantly enhanced the average value of soil fungi diversity compared with CT (Fig. 6). Soil fungal diversity decreased as the soil depth and N application increased under NT. However, fungal diversity of CT was not influenced by soil 
depth and $\mathrm{N}$ application also had no influence on it in 10-25 cm layer.

Principal component analysis of bacterial composition at the phylum level showed that two principal components accounted for $47.7 \%$ and $42.4 \%$ of the overall variances among these treatments in the $0-10 \mathrm{~cm}$ and 10-25 cm layers, respectively (Fig. 7). We also found that PCoA of the fungal composition showed that two principal components accounted for $46.5 \%$ and $39.2 \%$, respectively. We revealed that the two fractions (CT and NT) formed their clusters separated by PC1 in both layers. For fungi, the samples under the three N application rates of CT clustered closely, while samples within the NT differed more distinctly in the two layers.

\subsection{Soil fractions}

The POC and MAOC contents decreased with depth and were significantly affected by N application (Fig. $8 \mathrm{a}-\mathrm{b})$. NT increased the POC and MAOC contents by $12.1 \%$ and $10.1 \%$ compared with CT in the $0-10 \mathrm{~cm}$ layer, respectively. The POC and MAOC contents increased with increasing $\mathrm{N}$ application rates and the rate of increase under NT was higher than under CT in the 0-10 cm layer. However, tillage and N treatment had no influence on MAOC in the 10-25 cm layer.

\subsection{PLS-PM analysis}

To better integrate the interrelationships among $\mathrm{N}$ application, tillage practices, microbial communities, soil enzyme activities, soil microbial $\mathrm{CUE}_{\mathrm{C}: \mathrm{N}}$, POC, and MAOC, we constructed a partial least squares path model (Fig. 9). The indirect effect of tillage treatments $(0.38)$ on soil microbial $\mathrm{CUE}_{\mathrm{C}: \mathrm{N}}$ was larger than that of $\mathrm{N}$ application (0.13). We further found that tillage management and $\mathrm{N}$ application affected microbial $\mathrm{CUE}_{\mathrm{C}: \mathrm{N}}$ through changing soil bacterial diversity, fungal community structure, and fungus diversity more than bacterial and fungal biomass. The responses of microbial $\mathrm{CUE}_{\mathrm{C}: \mathrm{N}}$ to bacterial and fungal diversity were also different (Fig. 9). Moreover, the results showed that microbial $\mathrm{CUE}_{\mathrm{C}: \mathrm{N}}$ and soil enzyme activities had a direct effect on soil POC.

\section{Discussion}

\subsection{Soil microbial diversity and community structure}

Soil microbial communities are essential to maintaining soil ecosystem function and can be affected by tillage and N application (Bärlocher \& Boddy, 2016; Keszthelyi et al. , 2008). We found that NT treatment increased bacterial and fungal diversity in 0-10 cm layer compared to CT treatment (Tables S6 and S7). The difference between $\mathrm{CT}$ and NT could be due to the reduction of soil physical disturbance and protection from fungal hyphae and their mycelial network under the no-tillage system (Ceja-Navarro et al. , 2010; Verbruggen \& Toby Kiers, 2010; Wanget al. , 2017).

Furthermore, soil fungal and bacterial diversity decreased with increasing $\mathrm{N}$ application rates in the 0-10 $\mathrm{cm}$ layer and was higher under NT treatment than under CT (Figs. 5 and 9). One possible reason is that the straw in no-tillage has a wide $\mathrm{C} / \mathrm{N}$ ratio (Thierfelder et al. , 2018), which leads to an $\mathrm{N}$ limitation under this tillage system because microbe needs more $\mathrm{N}$ under this condition. A previous meta-analysis showed that appropriate $\mathrm{N}$ addition $\left(<100 \mathrm{~kg} \mathrm{~N}^{-1}\right.$ year $\left.^{-1}\right)$ is essential to stimulate microbial growth in no-tillage systems because it regulates soil C/N (Thierfelder et al. , 2018; Zhou et al. , 2017). However, excessive $\mathrm{N}$ fertilization suppresses the diversity of soil microbes because of the toxic effect of urea (Omar \& Ismail, 1999; Wang et al. , 2018). In this study, high $\mathrm{N}$ application rate $\left(210 \mathrm{~kg} \mathrm{~N}^{-1}\right)$ could induce toxicity, resulting in lesser microbial diversity. In addition, CT had lower soil SOC (Liet al. , 2010; Liu et al. , 2021) and C/N ratio compared with NT (Fiorini et al. ,2020), which leads to carbon limiting for microorganisms. Hence, the effect of $\mathrm{N}$ application had a smaller effect on microbial diversity under CT than NT. Previous studies showed that low $\mathrm{N}$ application (35-140 $\mathrm{kg} \mathrm{N} \mathrm{ha}^{-1}$ ) decreased soil bacterial diversity (Wanget al. , 2015) and our study highlighted that there was the same conclusion under high N application rate (105-210 $\mathrm{kg} \mathrm{N} \mathrm{ha}{ }^{-1}$ ), which extends our knowledge of the effect of $\mathrm{N}$ application on microbial diversity. In addition, increasing $\mathrm{N}$ application rates had a negative effect on some dominant flora such as Chloroflexi (Fig. 4), which also degrades SOM because Chloroflexi plays an important role in the decomposition of refractory $\mathrm{C}$ 
compounds (Li et al. , 2019b; Piazzaet al. , 2019). These results further indicate that N application needs to be considered when studying the effect of tillage management on microbial properties.

Tillage management could also influence the vertical distribution of soil microbial communities (Nunes et al. , 2020). We found no difference in enzyme activities, total PLFAs, and bacterial and fungal diversity among soil layers under CT treatment (Figs. 1, 2, 5, and 6). The main reason was that soil microbial communities in different soil layers would be similar to each other after homogenization induced by plowing under CT (Sun et al. , 2018). However, fungal and bacterial diversity decreased as soil depth increased under NT(Figs. 5 and 6), which was supported by the previous study (Jumpponen et al. , 2010). This was likely because no-tillage creates heterogeneous soil (Sun et al. , 2018). Moreover, the decrease rate of fungal and bacterial diversity with increasing soil depth was higher under N1 than N2 and N3 for NT treatment, indicating that a low $\mathrm{N}$ rate can enhance top soil bacterial and fungal diversity under NT. Hence, it is not sufficient to only consider the surface layer when investigating bacterial and fungal diversity response to $\mathrm{N}$ application rates in no-tillage systems.

\subsection{Relationship of soil microbial characteristic and microbial $C U E_{C: N}$}

Soil microbial CUE can affect soil C cycling (Spohn et al. , 2016). We found that NT increased the soil microbial $\mathrm{CUE}_{\mathrm{C}: \mathrm{N}}$ on average compared with $\mathrm{CT}$ (Fig. 2) because no-tillage can decrease soil temperature by surface mulching and further increase microbial CUE (Apple et al. , 2006; Wetterstedt \& Agren, 2011). In addition, higher residue production under NT is constantly supplying fresh and labile organic substrates for microbial activity and biomass thus explaining the greater CUE observed under NT compared with CT (Alvaro-Fuentes et al. , 2013). Microbial $\mathrm{CUE}_{\mathrm{C}: \mathrm{N}}$ increased with increasing $\mathrm{N}$ application under both tillage treatments (Fig. 2). The reason is that $\mathrm{N}$ addition can reduce microbial respiration metabolism (Liuet al. , 2018; Spohn et al. , 2016; Thiet et al. , 2006) and increase microbial biomass (Jha et al. , 2020), resulting in higher microbial $\mathrm{CUE}_{\mathrm{C}: \mathrm{N}}$.

Furthermore, although a recent study showed that microbial diversity drives CUE in artificial soil (Domeignoz-Horta et al. , 2020), to the best of our knowledge, few experimental studies have directly demonstrated the interaction effect of tillage management and $\mathrm{N}$ application on microbial CUE in a field experiment. In this study, the PLS-PM showed that tillage and nitrogen influenced microbial CUE $_{\mathrm{C}: \mathrm{N}}$ through the microbial diversity and community structure (Fig. 9). We also found that the bacterial and fungal diversity had different influences on microbial $\mathrm{CUE}_{\mathrm{C}: \mathrm{N}}$ (Fig. 9) under two tillage and these relationships were regulated by $\mathrm{N}$ application (Fig. S1) under no-tillage. Bacterial diversity positively influenced microbial $\mathrm{CUE}_{\mathrm{C}: \mathrm{N}}$, whereas fungal diversity had an adverse impact on microbial CUE $\mathrm{C}: \mathrm{N}$ (Fig. 9). The difference points to the importance of studying the diversity of fungal and bacterial communities separately for predicting soil $\mathrm{C}$ cycling. In addition, microbial network complexity driving carbon cycling with direct feedback effects on multiple ecosystem functions (Morrien et al. , 2017; Wagg et al. , 2019; Zhou et al. , 2010), which could also influence microbial CUE. Further research should be undertaken to explore the effect of bacterial and fungal networks on microbial $\mathrm{CUE}_{\mathrm{C}: \mathrm{N}}$.

\subsection{The influence of microbial $C U E_{C: N}$ on soil POC and MAOC fractions}

POC is a functional soil component for persistent soil organic carbon (Witzgall et al. , 2021). In contrast to POC, MAOC is more physically or chemically protected, which makes it less vulnerable to mineralization (Abramoff et al. , 2018). We found that high $\mathrm{N}$ application $\left(210 \mathrm{~kg} \mathrm{~N} \mathrm{ha}^{-1}\right)$ increased POC and MAOC content under two tillage practices (Fig. 9), which is similar to the previous study (Ye et al. , 2018). The possible reason was that plant biomass (Stewartet al. , 2016; Thomas et al. , 2010; Wang et al. , 2018) and microbial residues (Chen et al. , 2020a) increased with increasing $\mathrm{N}$ application. However, some discrepant findings showed that $\mathrm{N}$ addition decreased (Ye et al. , 2018) or had no significant influence on MAOC (Yuan et al. , 2020). The main reason for the inconsistent results could be that microbial residues controlled the changes of soil MAOC pool under $\mathrm{N}$ addition and the microbial residues were different due to different $\mathrm{N}$ application rates among these studies (Averill \& Waring, 2018; Chen et al. , 2020a; Su et al. , 2020; Yang et al. , 2020b). 
We further found that the $\mathrm{CUE}_{\mathrm{C}: \mathrm{N}}$ was significantly positively correlated with POC and MAOC and the increase rates were higher under NT than $\mathrm{CT}$, which was influenced by nitrogen application (Fig. S2). Moreover, the POC also had a positive effect on MAOC (Fig. 9) because a portion of POC was degraded by microbes and then formed part of the MAOC (Su et al. , 2020). Therefore, these results highlight that nitrogen regulates the influence of microbial $\mathrm{CUE}_{\mathrm{C}: \mathrm{N}}$ on soil organic carbon fractions under tillage practices.

\section{Conclusions}

$\mathrm{N}$ application could alter the effects of tillage practices on soil microbial diversity, community composition, biomass, and CUE. Bacterial and fungal diversities were more responsible for soil microbial $\mathrm{CUE}_{\mathrm{C}: \mathrm{N}}$ than their biomass. Although microbial $\mathrm{CUE}_{\mathrm{C}: \mathrm{N}}$ was more susceptible to tillage management than $\mathrm{N}$ application, it

increased with an increasing in $\mathrm{N}$ application rate under the two tillage practices. Furthermore, soil microbial $\mathrm{CUE}_{\mathrm{C}: \mathrm{N}}$ increased soil POC and MAOC contents and $\mathrm{N}$ application also increased the two SOC fractions. This research underscores the importance of $\mathrm{N}$ application to reveal the effect of tillage management on POC and MAOC from the perspective of soil microbial properties, which contributes to understanding the potential $\mathrm{C}$ sequestration benefits of $\mathrm{N}$ application under no-tillage.

\section{Acknowledgments}

This research was supported by the National Natural Science Foundation of China (4210071364), the Ministerial and Provincial Co-Innovation Centre for Endemic Crops Production with High-quality and Efficiency in Loess Plateau, Taigu 030801, China (SBGJXTZXKF-02), the National Key Research and Development Program of China (2018YFE0112300 and 2018YFD0200408). We wish to thank the editors and reviewers for their constructive comments.

\section{References}

Abramoff R, Xu X, Hartman M, O’Brien S, Feng W, Davidson E, Finzi A, Moorhead D, Schimel J, Torn M, Mayes MA. 2018. The Millennial model: in search of measurable pools and transformations for modeling soil carbon in the new century. Biogeochemistry 137 : 51-71. DOI: 10.1007/s10533-017-0409-7

Adu JK, Oades JM. 1978. Utilization of organic materials in soil aggregates by bacteria and fungi. Soil Biology and Biochemistry10 : 117-122. DOI: 10.1016/0038-0717(78)90081-0

Ai C, Zhang S, Zhang X, Guo D, Zhou W, Huang S. 2018. Distinct responses of soil bacterial and fungal communities to changes in fertilization regime and crop rotation. Geoderma 319: 156-166. DOI: 10.1016/j.geoderma.2018.01.010

Alvaro-Fuentes J, Morell FJ, Madejon E, Lampurlanes J, Arrue JL, Cantero-Martinez C. 2013. Soil biochemical properties in a semiarid Mediterranean agroecosystem as affected by long-term tillage and $\mathrm{N}$ fertilization. Soil and Tillage Research 129 : 69-74. DOI: 10.1016/j.still.2013.01.005

Apple JK, Del Giorgio PA, Kemp WM. 2006. Temperature regulation of bacterial production, respiration, and growth efficiency in a temperate salt-marsh estuary. Aquatic Microbial Ecology 43 : 243-254. DOI: 10.3354/ame043243

Averill C, Waring B. 2018. Nitrogen limitation of decomposition and decay: How can it occur? Global Change Biology 24 : 1417-1427. DOI: 10.1111/gcb.13980

Barlocher F, Boddy L. 2016. Aquatic fungal ecology - How does it differ from terrestrial? Fungal Ecology 19 : 5-13. DOI: 10.1016/j.funeco.2015.09.001

Borjesson G, Sundh I, Tunlid A, Svensson BH. 1998. Methane oxidation in landfill cover soils, as revealed by potential oxidation measurements and phospholipid fatty acid analyses. Soil Biology and Biochemistry 30 : 1423-1433. DOI: 10.1016/S0038-0717(97)00257-5

Bradford MA, Keiser AD, Davies CA, Mersmann CA, Strickland MS. 2013. Empirical evidence that soil carbon formation from plant inputs is positively related to microbial growth. Biogeochemistry113 : 271-281. 
DOI: $10.1007 / \mathrm{s} 10533-012-9822-0$

Brockett BFT, Prescott CE, Grayston SJ. 2012. Soil moisture is the major factor influencing microbial community structure and enzyme activities across seven biogeoclimatic zones in western Canada. Soil Biology and Biochemistry 44 : 9-20. DOI: 10.1016/j.soilbio.2011.09.003

Caporaso. 2010. Intensity normalization improves color calling in SOLiD sequencing. Nature Methods 7 : 336-337. DOI: 10.1038/nmeth0510-336

Ceja-Navarro JA, Rivera-Orduna FN, Patino-Zuniga L, Vila-Sanjurjo A, Crossa J, Govaerts B, Dendooven L. 2010. Phylogenetic and multivariate analyses to determine the effects of different tillage and residue management practices on soil bacterial communities. Applied and Environmental Microbiology 76 : 36853691. DOI: 10.1128/AEM.02726-09

Chen H, Li D, Feng W, Niu S, Plante A, Luo Y, Wang K. 2018. Different responses of soil organic carbon fractions to additions of nitrogen.European Journal of Soil Science 69 : 1098-1104. DOI: 10.1111/ejss.12716

Chen J, Ji C, Fang J, He H, Zhu B. 2020a. Dynamics of microbial residues control the responses of mineralassociated soil organic carbon to N addition in two temperate forests. Science of the Total Environment $\mathbf{7 4 8}$ : 141318. DOI: $10.1016 /$ j.scitotenv.2020.141318

Chen J, Xiao W, Zheng C, Zhu B. 2020b. Nitrogen addition has contrasting effects on particulate and mineral-associated soil organic carbon in a subtropical forest. Soil Biology and Biochemistry 142 : 107708. DOI: $10.1016 /$ j.soilbio.2020.107708

Chen S, Wang W, Xu W, Wang Y, Wan H, Chen D, Tang Z. 2017. Plant diversity enhances productivity and soil carbon storage. 2017 . DOI: 10.1073/pnas.1700298114

Chen Y, Liu X, Hou Y, Zhou S, Zhu B. 2019. Particulate organic carbon is more vulnerable to nitrogen addition than mineral-associated organic carbon in soil of an alpine meadow. Plant and Soil . DOI: 10.1007/s11104-019-04279-4

Chowdhury TR, Dick RP. 2012. Standardizing methylation method during phospholipid fatty acid analysis to profile soil microbial communities.Journal of Microbiological Methods 88 : 285-291. DOI: 10.1016/j.mimet.2011.12.008

Cleveland CC, Liptzin D. 2007. C:N:P stoichiometry in soil: Is there a "Redfield ratio" for the microbial biomass? Biogeochemistry85 : 235-252. DOI: 10.1007/s10533-007-9132-0

Curtin D, Beare MH, Qiu W, Sharp J. 2019. Does Particulate Organic Matter Fraction Meet the Criteria for a Model Soil Organic Matter Pool? Pedosphere 29 : 195-203. DOI: 10.1016/S1002-0160(18)60049-9

De valenca AW, Vanek SJ, Meza K, Ccanto R, Olivera E. 2017. Land use as a driver of soil fertility and biodiversity across agricultural landscape in the Central Peruvian Andes. 27 : 1138-1154. DOI: 10.1002/eap. 1508

Domeignoz-Horta LA, Pold G, Liu XJA, Frey SD, Melillo JM, DeAngelis KM. 2020. Microbial diversity drives carbon use efficiency in a model soil.Nature Communications 11 : 1-10. DOI: 10.1038/s41467-02017502-z

Fang Y, Singh BP, Cowie A, Wang W, Arachchi MH, Wang H, Tavakkoli E. 2019. Balancing nutrient stoichiometry facilitates the fate of wheat residue-carbon in physically defined soil organic matter fractions.Geoderma 354 : 113883. DOI: 10.1016/j.geoderma.2019.113883

Fiorini A, Boselli R, Maris SC, Santelli S, Ardenti F, Capra F, Tabaglio V. 2020. May conservation tillage enhance soil $\mathrm{C}$ and $\mathrm{N}$ accumulation without decreasing yield in intensive irrigated croplands? Results from an eight-year maize monoculture. Agriculture, Ecosystems and Environment 296 : 106926. DOI: 10.1016/j.agee.2020.106926 
Frostegard A, Baath E. 1996. The use of phospholipid fatty acid analysis to estimate bacterial and fungal biomass in soil. Biology and Fertility of Soils 22 : 59-65. DOI: 10.1007/s003740050076

Gentile R, Vanlauwe B, Chivenge P, Six J. 2011. Trade-offs between the short- and long-term effects of residue quality on soil C and N dynamics. Plant and Soil 338 : 159-169. DOI: 10.1007/s11104-010-0360-z

Geyer KM, Dijkstra P, Sinsabaugh R, Frey SD. 2019. Clarifying the interpretation of carbon use efficiency in soil through methods comparison. Soil Biology and Biochemistry 128 : 79-88. DOI: 10.1016/j.soilbio.2018.09.036

Haddix ML, Paul EA, Cotrufo MF. 2016. Dual, differential isotope labeling shows the preferential movement of labile plant constituents into mineral-bonded soil organic matter. Global Change Biology22 : 2301-2312. DOI: $10.1111 /$ gcb.13237

Herath HMSK, Camps-Arbestain M, Hedley M, Van Hale R, Kaal J. 2014. Fate of biochar in chemically- and physically-defined soil organic carbon pools. Organic Geochemistry 73 : 35-46. DOI: 10.1016/j.orggeochem.2014.05.001

Huang R, Zhang Z, Xiao X, Zhang N, Wang X, Yang Z, Xu K, Liang Y. 2019. Structural changes of soil organic matter and the linkage to rhizosphere bacterial communities with biochar amendment in manure fertilized soils.Science of the Total Environment 692 : 333-343. DOI: 10.1016/j.scitotenv.2019.07.262

Jenkinson DS, Brookes PC, Powlson DS. 2004. Measuring soil microbial biomass. Soil Biology and Biochemistry 36 : 5-7. DOI: 10.1016/j.soilbio.2003.10.002

Jha P, Hati KM, Dalal RC, Dang YP, Kopittke PM, Menzies NW. 2020. Soil carbon and nitrogen dynamics in a Vertisol following 50 years of no-tillage, crop stubble retention and nitrogen fertilization. Geoderma $\mathbf{3 5 8}$ : 113996. DOI: 10.1016/j.geoderma.2019.113996

Jumpponen A, Jones KL, Blair J. 2010. Vertical distribution of fungal communities in tallgrass prairie soil. Mycologia 102 : 1027-1041. DOI: 10.3852/09-316

Kallenbach CM, Wallenstein MD, Schipanksi ME, Stuart Grandy A. 2019. Managing agroecosystems for soil microbial carbon use efficiency: Ecological unknowns, potential outcomes, and a path forward.Frontiers in Microbiology 10 . DOI: 10.3389/fmicb.2019.01146

Keiblinger KM, Hall EK, Wanek W, Szukics U, Hammerle I, Ellersdorfer G, Bock S, Strauss J, Sterflinger K, Richter A, Zechmeister-Boltenstern S. 2010. The effect of resource quantity and resource stoichiometry on microbial carbon-use-efficiency. FEMS Microbiology Ecology73 : 430-440. DOI: 10.1111/j.15746941.2010.00912.x

Keszthelyi A, Hamari Z, Pfeiffer I, Vagvolgyi C, Kucsera J. 2008. Comparison of killer toxin-producing and non-producing strains of Filobasidium capsuligenum: Proposal for two varieties.Microbiological Research 163 : 267-276. DOI: 10.1016/j.micres.2008.01.002

Lee SH, Malone C, Kemp PF. 1993. Use of multiple 16S rRNA-targeted fluorescent probes to increase signal strength and measure cellular RNA from natural planktonic bacteria. Marine Ecology Progress Series 101 : 193-202. DOI: 10.3354/meps101193

Lee ZM, Schmidt TM. 2014. Bacterial growth efficiency varies in soils under different land management practices. Soil Biology and Biochemistry 69 : 282-290. DOI: 10.1016/j.soilbio.2013.11.012

Li J, Wang G, Allison SD, Mayes MA. 2014. Soil carbon sensitivity to temperature and carbon use efficiency compared across microbial-ecosystem models of varying complexity. 67-84. DOI: 10.1007/s10533-013-9948-8

Li J, Wang G, Mayes MA, Allison SD, Frey SD, Shi Z, Hu XM, Luo Y, Melillo JM. 2019a. Reduced carbon use efficiency and increased microbial turnover with soil warming. Global Change Biology 25 : 900-910. DOI: $10.1111 /$ gcb.14517 
Li S, Wu X, Liang G, Gao L, Wang B, Lu J, Abdelrhman AA, Song X, Zhang M, Zheng F, Degre A. 2020. Is least limiting water range a useful indicator of the impact of tillage management on maize yield? Soil and Tillage Research 199 : 104602. DOI: 10.1016/j.still.2020.104602

Li Y, Nie C, Liu Y, Du W, He P. 2019b. Soil microbial community composition closely associates with specific enzyme activities and soil carbon chemistry in a long-term nitrogen fertilized grassland.Science of the Total Environment 654 : 264-274. DOI: 10.1016/j.scitotenv.2018.11.031

Li Z, Liu M, Wu X, Han F, Zhang T. 2010. Effects of long-term chemical fertilization and organic amendments on dynamics of soil organic $\mathrm{C}$ and total $\mathrm{N}$ in paddy soil derived from barren land in subtropical China.Soil and Tillage Research 106 : 268-274. DOI: 10.1016/j.still.2009.12.008

Liu W, Qiao C, Yang S, Bai W, Liu L. 2018. Microbial carbon use efficiency and priming effect regulate soil carbon storage under nitrogen deposition by slowing soil organic matter decomposition. Geoderma 332 : 37-44. DOI: 10.1016/j.geoderma.2018.07.008

Liu X, Wu X, Liang G, Zheng F, Zhang M, Li S. 2021. A global meta-analysis of the impacts of no-tillage on soil aggregation and aggregate-associated organic carbon. Land Degradation $\mathcal{E}$ Development $\mathbf{n} / \mathbf{a}$. DOI: https://doi.org/10.1002/ldr.4109

Luan C, Xie L, Yang X, Miao H, Lv N, Zhang R, Xiao X, Hu Y, Liu Y, Wu N, Zhu Y, Zhu B. 2015. Dysbiosis of fungal microbiota in the intestinal mucosa of patients with colorectal adenomas. Scientific Reports5 : 1-9. DOI: $10.1038 /$ srep07980

Manzoni S, Taylor P, Richter A, Porporato A, Agren GI. 2012. Environmental and stoichiometric controls on microbial carbon-use efficiency in soils. New Phytologist 196 : 79-91. DOI: 10.1111/j.1469-8137.2012.04225.x

Mo F, Zhang YY, Liu Y, Liao YC. 2021. Microbial carbon-use efficiency and straw-induced priming effect within soil aggregates are regulated by tillage history and balanced nutrient supply. Biology and Fertility of Soils 57 : 409-420. DOI: 10.1007/s00374-021-01540-w

Morrien E, Hannula SE, Snoek LB, Helmsing NR, Zweers H, De Hollander M, Soto RL, Bouffaud ML, Buee M, Dimmers W, Duyts H, Geisen S, Girlanda M, Griffiths RI, Jorgensen HB, Jensen J, Plassart P, Redecker D, Schmelz RM, Schmidt O, Thomson BC, Tisserant E, Uroz S, Winding A, Bailey MJ, Bonkowski M, Faber JH, Martin F, Lemanceau P, De Boer W, Van Veen JA, Van Der Putten WH. 2017. Soil networks become more connected and take up more carbon as nature restoration progresses. Nature Communications 8. DOI: $10.1038 /$ ncomms 14349

Novara A, Gristina L, Sala G, Galati A, Crescimanno M, Cerda A, Badalamenti E, La T. 2017. Science of the Total Environment Agricultural land abandonment in Mediterranean environment provides ecosystem services via soil carbon sequestration. Science of the Total Environment 576 : 420-429. DOI: 10.1016/j.scitotenv.2016.10.123

Nunes MR, Karlen DL, Veum KS, Moorman TB, Cambardella CA. 2020. Biological soil health indicators respond to tillage intensity: A US meta-analysis. Geoderma 369 : 114335 . DOI: 10.1016/j.geoderma.2020.114335

Omar SA, Ismail MA. 1999. Microbial populations, ammonification and nitrification in soil treated with urea and inorganic salts. Folia Microbiologica 44 : 205-212. DOI: 10.1007/BF02816244

Piazza G, Ercoli L, Nuti M, Pellegrino E. 2019. Interaction Between Conservation Tillage and Nitrogen Fertilization Shapes Prokaryotic and Fungal Diversity at Different Soil Depths: Evidence From a 23-Year Field Experiment in the Mediterranean Area. Frontiers in Microbiology10 : 1-20. DOI: 10.3389/fmicb.2019.02047

Qiao Y, Wang J, Liang G, Du Z, Zhou J, Zhu C. 2019. Global variation of soil microbial carbon-use efficiency in relation to growth temperature and substrate supply. 1-8. DOI: 10.1038/s41598-019-42145-6 
Saiya-Cork KR, Sinsabaugh RL, Zak DR. 2002. The effects of long term nitrogen deposition on extracellular enzyme activity in an Acer saccharum forest soil. Soil Biology and Biochemistry 34 : 1309-1315. DOI: 10.1016/S0038-0717(02)00074-3

Sauvadet M, Lashermes G, Alavoine G, Recous S, Chauvat M, Maron PA, Bertrand I. 2018. High carbon use efficiency and low priming effect promote soil C stabilization under reduced tillage. Soil Biology and Biochemistry 123 : 64-73. DOI: 10.1016/j.soilbio.2018.04.026

Sinsabaugh RL, Findlay S, Franchini P, Fischer D. 1997. Enzymatic analysis of riverine bacterioplankton production. Limnology and Oceanography 42 : 29-38. DOI: 10.4319/lo.1997.42.1.0029

Sinsabaugh RL, Shah JJF. 2012. Ecoenzymatic stoichiometry and ecological theory. Annual Review of Ecology, Evolution, and Systematics43 : 313-343. DOI: 10.1146/annurev-ecolsys-071112-124414

Sinsabaugh, Turner BL, Talbot JM, Waring BG, Powers JS, Kuske CR, Moorhead DL, Shah JJF. 2016. Stoichiometry of microbial carbon use efficiency in soils. Ecological Monographs 86 : 172-189. DOI: 10.1890/152110.1

Six J, Elliott ET, Paustian K, Doran JW. 1998. Aggregation and Soil Organic Matter Accumulation in Cultivated and Native Grassland Soils.Soil Science Society of America Journal 62 : 1367-1377. DOI: 10.2136/sssaj1998.03615995006200050032x

Six J, Frey SD, Thiet RK, Batten KM. 2006. Bacterial and Fungal Contributions to Carbon Sequestration in Agroecosystems. Soil Science Society of America Journal 70 : 555-569. DOI: 10.2136/sssaj2004.0347

Spohn M, Potsch EM, Eichorst SA, Woebken D, Wanek W, Richter A. 2016. Soil microbial carbon use efficiency and biomass turnover in a long-term fertilization experiment in a temperate grassland. Soil Biology and Biochemistry 97 : 168-175. DOI: 10.1016/j.soilbio.2016.03.008

Stewart CE, Follett RF, Pruessner EG, Varvel GE, Vogel KP, Mitchell RB. 2016. N fertilizer and harvest impacts on bioenergy crop contributions to SOC. GCB Bioenergy 8 : 1201-1211. DOI: 10.1111/gcbb.12326

$\mathrm{Su}$ Y, He Z, Yang Y, Jia S, Yu M, Chen X, Shen A. 2020. Linking soil microbial community dynamics to straw-carbon distribution in soil organic carbon. Scientific Reports 10 : 1-12. DOI: 10.1038/s41598-020$62198-2$

Sun R, Li W, Dong W, Tian Y, Hu C, Liu B. 2018. Tillage changes vertical distribution of soil bacterial and fungal communities. Frontiers in Microbiology 9 : 1-13. DOI: 10.3389/fmicb.2018.00699

Thierfelder C, Baudron F, Setimela P, Nyagumbo I, Mupangwa W, Mhlanga B, Lee N, Gerard B. 2018. Complementary practices supporting conservation agriculture in southern Africa. A review. Agronomy for Sustainable Development 38 . DOI: 10.1007/s13593-018-0492-8

Thiet RK, Frey SD, Six J. 2006. Do growth yield efficiencies differ between soil microbial communities differing in fungal:bacterial ratios? Reality check and methodological issues. Soil Biology and Biochemistry 38 : 837-844. DOI: 10.1016/j.soilbio.2005.07.010

Thomas RQ, Canham CD, Weathers KC, Goodale CL. 2010. Increased tree carbon storage in response to nitrogen deposition in the US.Nature Geoscience 3 : 13-17. DOI: 10.1038/ngeo721

Van Groenigen KJ, Forristal D, Jones M, Smyth N, Schwartz E, Hungate B, Dijkstra P. 2013. Using metabolic tracer techniques to assess the impact of tillage and straw management on microbial carbon use efficiency in soil. Soil Biology and Biochemistry 66 : 139-145. DOI: 10.1016/j.soilbio.2013.07.002

Verbruggen E, Toby Kiers E. 2010. Evolutionary ecology of mycorrhizal functional diversity in agricultural systems. Evolutionary Applications 3 : 547-560. DOI: 10.1111/j.1752-4571.2010.00145.x

Wagg C, Schlaeppi K, Banerjee S, Kuramae EE, van der Heijden MGA. 2019. Fungal-bacterial diversity and microbiome complexity predict ecosystem functioning. Nature Communications 10 : 1-10. DOI: 


\subsection{8/s41467-019-12798-y}

Waldrop MP, Firestone MK. 2004. Microbial community utilization of recalcitrant and simple carbon compounds: Impact of oak-woodland plant communities. Oecologia 138 : 275-284. DOI: 10.1007/s00442-0031419-9

Wang B, Gao L, Yu W, Wei X, Li J, Li S, Song X, Liang G, Cai D, Wu X. 2019. Distribution of soil aggregates and organic carbon in deep soil under long-term conservation tillage with residual retention in dryland.Journal of Arid Land 11 : 241-254. DOI: 10.1007/s40333-019-0094-6

Wang C, Liu D, Bai E. 2018. Decreasing soil microbial diversity is associated with decreasing microbial biomass under nitrogen addition.Soil Biology and Biochemistry 120 : 126-133. DOI: 10.1016/j.soilbio.2018.02.003

Wang J, Bao J, Su J, Li X, Chen G, Ma X. 2015. Impact of inorganic nitrogen additions on microbes in biological soil crusts. Soil Biology and Biochemistry 88 : 303-313. DOI: 10.1016/j.soilbio.2015.06.004

Wang Y, Li C, Tu C, Hoyt GD, DeForest JL, Hu S. 2017. Long-term no-tillage and organic input management enhanced the diversity and stability of soil microbial community. Science of the Total Environment 609 : 341-347. DOI: 10.1016/j.scitotenv.2017.07.053

Wang Z, Li T, Li Y, Zhao D, Han J, Liu Y, Liao Y. 2020. Relationship between the microbial community and catabolic diversity in response to conservation tillage. Soil and Tillage Research 196 : 104431 . DOI: 10.1016/j.still.2019.104431

Wetterstedt JAM, Agren GI. 2011. Quality or decomposer efficiency - Which is most important in the temperature response of litter decomposition? A modelling study using the GLUE methodology.Biogeosciences 8 : 477-487. DOI: $10.5194 /$ bg-8-477-2011

White D, Stair J, Ringelberg D. 1996. Quantitative comparisons ofin situ microbial biodiversity by signature biomarker analysis. Journal of Industrial Microbiology \& Biotechnology 17 : 185-196. DOI: $10.1007 / \mathrm{bf01574692}$

Widdig M, Schleuss PM, Biederman LA, Borer ET, Crawley MJ, Kirkman KP, Seabloom EW, Wragg PD, Spohn M. 2020. Microbial carbon use efficiency in grassland soils subjected to nitrogen and phosphorus additions.Soil Biology and Biochemistry 146 : 107815. DOI: 10.1016/j.soilbio.2020.107815

Willers C, Jansen van Rensburg PJ, Claassens S. 2015. Phospholipid fatty acid profiling of microbial communities-a review of interpretations and recent applications. Journal of Applied Microbiology119 : 1207-1218. DOI: 10.1111/jam.12902

Witzgall K, Vidal A, Schubert DI, Hoschen C, Schweizer SA, Buegger F, Pouteau V, Chenu C, Mueller CW. 2021. Particulate organic matter as a functional soil component for persistent soil organic carbon. Nature communications 12 : 4115. DOI: 10.1038/s41467-021-24192-8

Yang H, Wu G, Mo P, Chen S, Wang S, Xiao Y, Ma H ang, Wen T, Guo X, Fan G. 2020a. The combined effects of maize straw mulch and no-tillage on grain yield and water and nitrogen use efficiency of dry-land winter wheat (Triticum aestivum L.). Soil and Tillage Research197 . DOI: 10.1016/j.still.2019.104485

Yang Y, Cheng H, Gao H, An S. 2020b. Response and driving factors of soil microbial diversity related to global nitrogen addition. Land Degradation and Development 31 : 190-204. DOI: 10.1002/ldr.3439

Ye C, Chen D, Hall SJ, Pan S, Yan X, Bai T, Guo H, Zhang Y, Bai Y, Hu S. 2018. Reconciling multiple impacts of nitrogen enrichment on soil carbon: plant, microbial and geochemical controls. Ecology Letters 21 : 1162-1173. DOI: 10.1111/ele.13083

Yuan X, Qin W, Xu H, Zhang Z, Zhou H, Zhu B. 2020. Sensitivity of soil carbon dynamics to nitrogen and phosphorus enrichment in an alpine meadow. Soil Biology and Biochemistry 150 : 107984 . DOI: 10.1016/j.soilbio.2020.107984 
Zhou J, Deng Y, Luo F, He Z, Tu Q, Zhi X. 2010. Functional molecular ecological networks. mBio 1 : 1-10. DOI: $10.1128 / \mathrm{mBio} .00169-10$

Zhou Z, Wang C, Zheng M, Jiang L, Luo Y. 2017. Patterns and mechanisms of responses by soil microbial communities to nitrogen addition.Soil Biology and Biochemistry 115: 433-441. DOI: 10.1016/j.soilbio.2017.09.015

Zhou Z, Zhang H, Yuan Z, Gong R. 2020. The nutrient release rate accounts for the effect of organic matter type on soil microbial carbon use efficiency of a Pinus tabulaeformis forest in northern China. Journal of Soils and Sediments 20 : 352-364. DOI: 10.1007/s11368-019-02423-2Table 1 Soil physical and chemical properties in 0-25 cm layer in 2003.

\begin{tabular}{lllllllll}
\hline & $\begin{array}{l}\text { Soil } \\
\text { particle size } \\
\text { distribution } \\
(\%)\end{array}$ & $\begin{array}{l}\text { Soil } \\
\text { particle size } \\
\text { distribution } \\
(\%)\end{array}$ & $\begin{array}{l}\text { Soil layer } \\
\text { particle size } \\
\text { distribution } \\
(\%)\end{array}$ & $\begin{array}{l}\text { Available } \\
\text { soil } \\
\text { nutrient } \\
\left(\mathrm{mg} \mathrm{kg}^{-1}\right)\end{array}$ & $\begin{array}{l}\text { Available } \\
\text { soil } \\
\text { nutrient } \\
\left(\mathrm{mg} \mathrm{kg}^{-1}\right)\end{array}$ & $\begin{array}{l}\text { Available } \\
\text { soil } \\
\text { nutrient } \\
\left(\mathrm{mg} \mathrm{kg}^{-1}\right)\end{array}$ & $\begin{array}{l}\mathrm{SOC}(\mathrm{g} \\
\left.\mathrm{kg}^{-1}\right)\end{array}$ & $\begin{array}{l}\text { Bulk } \\
\text { density } \\
\left.\mathrm{cm}^{-3}\right)\end{array}$ \\
\hline & $\begin{array}{l}>0.020 \\
\mathrm{~mm}\end{array}$ & $\begin{array}{l}0.002- \\
0.020\end{array}$ & $\begin{array}{l}<0.002 \\
\mathrm{~mm}\end{array}$ & $\mathrm{~N}$ & $\mathrm{P}$ & $\mathrm{K}$ & & \\
& & $\mathrm{mm}$ & & & & & & \\
$0-10$ & 58.5 & 35.7 & 5.8 & 58 & 8.3 & 96 & 22.7 & 1.06 \\
$10-25$ & 59.6 & 34.6 & 5.8 & 52 & 6.9 & 93 & 19.8 & 1.2 \\
\hline
\end{tabular}



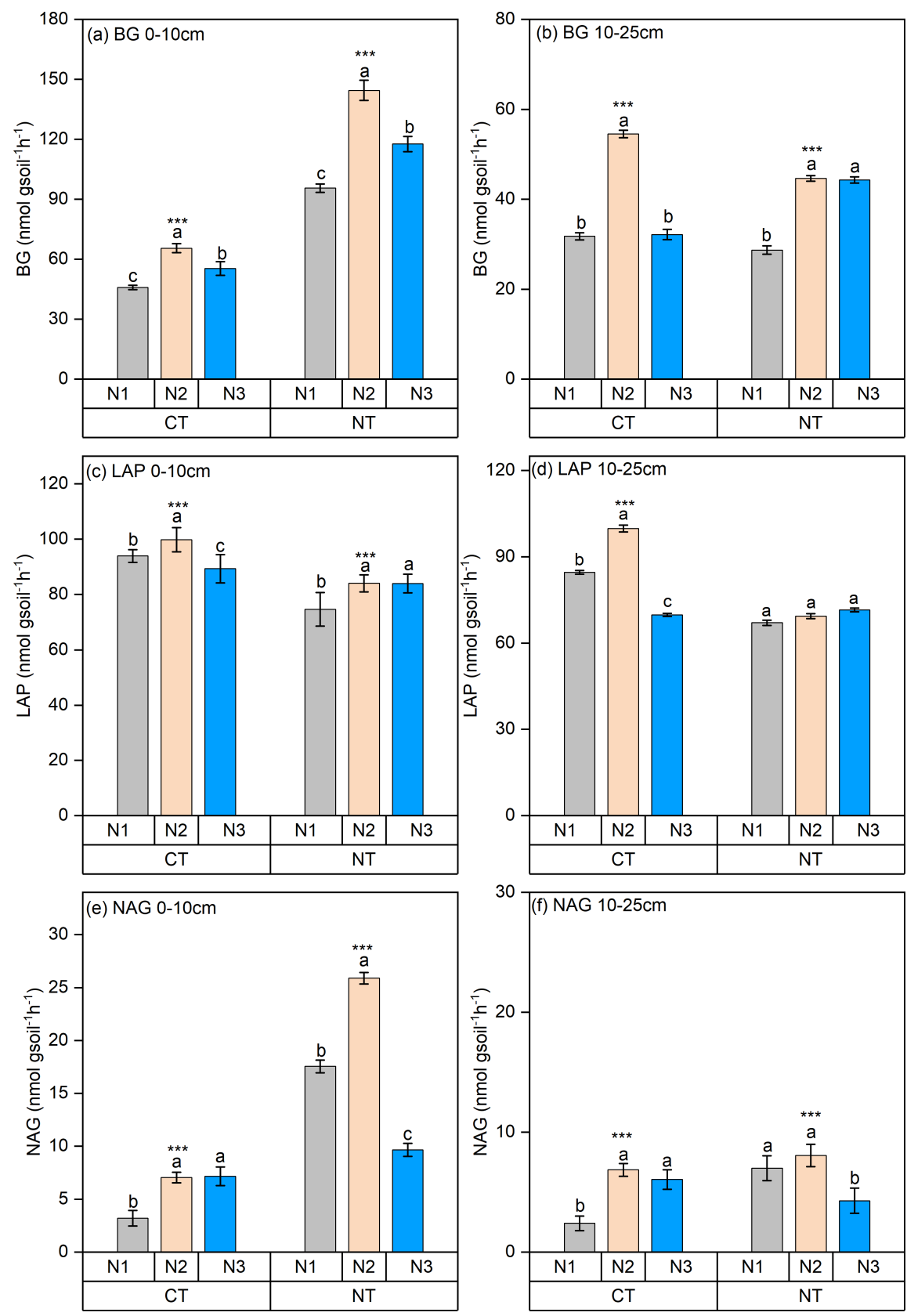

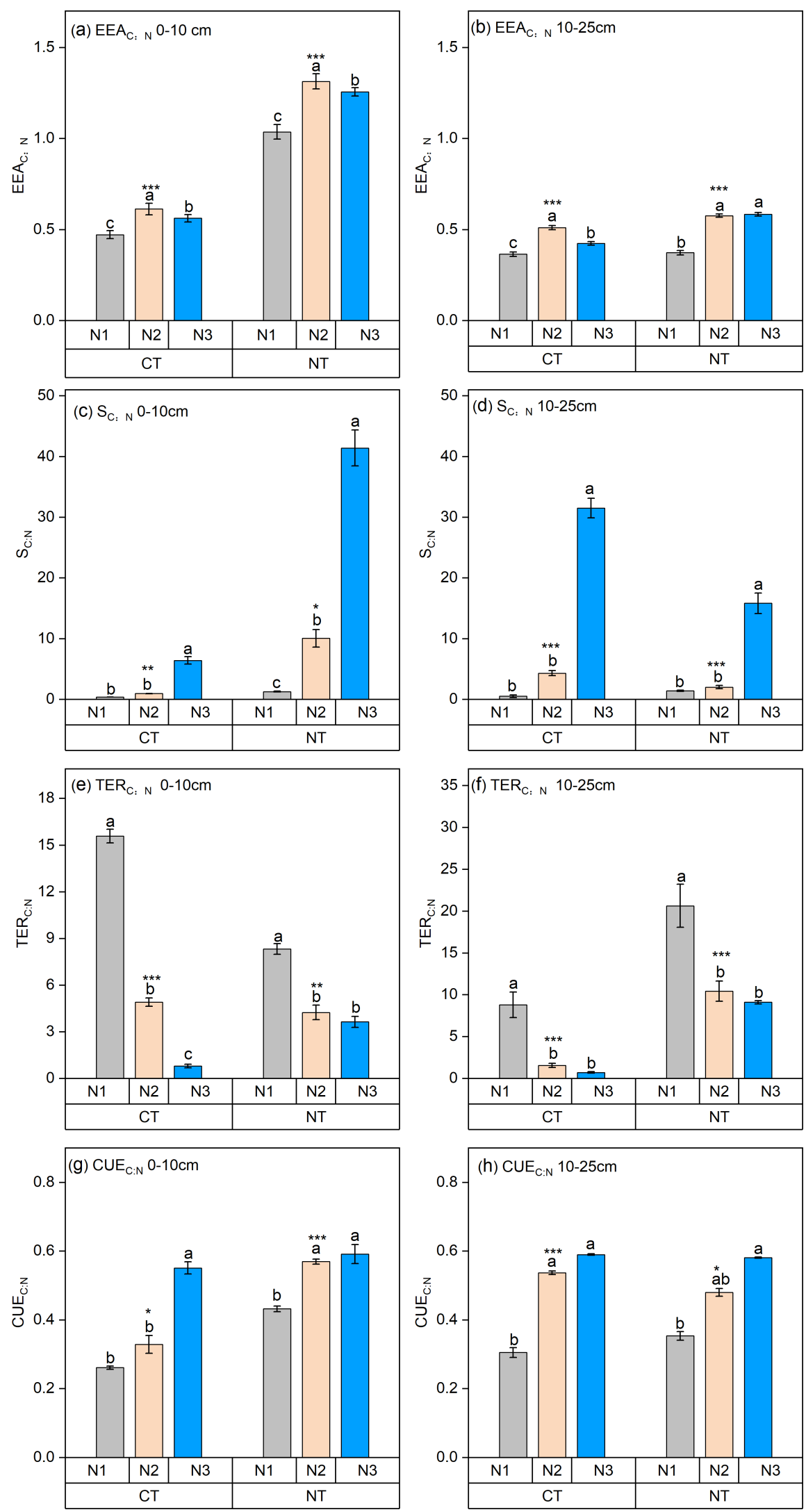

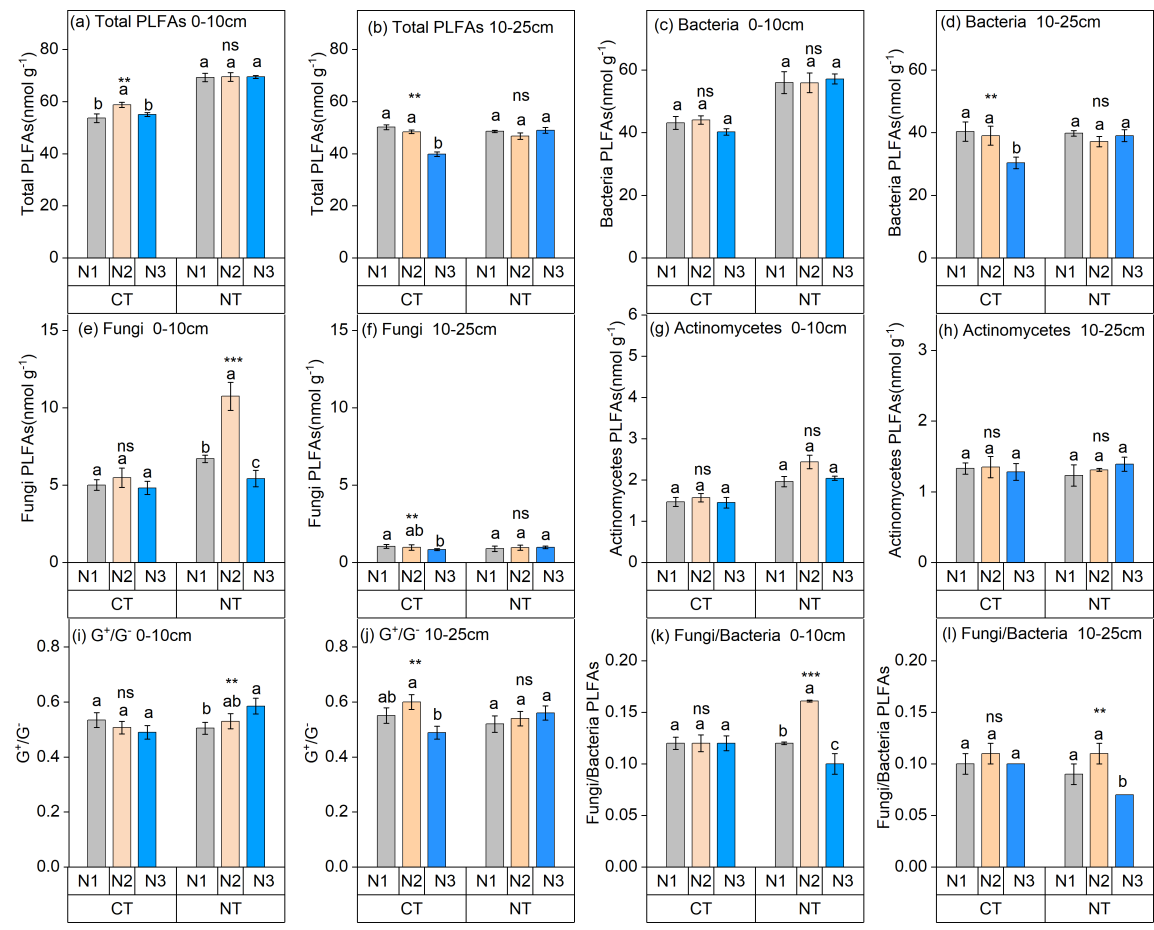
(a) Bacteria relative aboundance $0-10 \mathrm{~cm}$
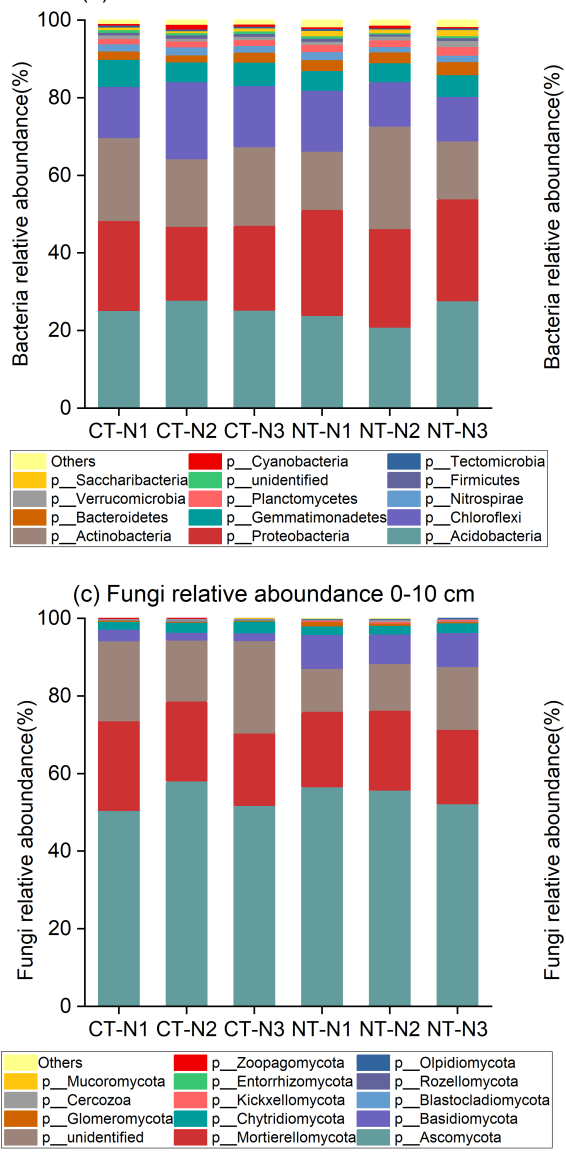

(b) Bacteria relative aboundance $10-25 \mathrm{~cm}$

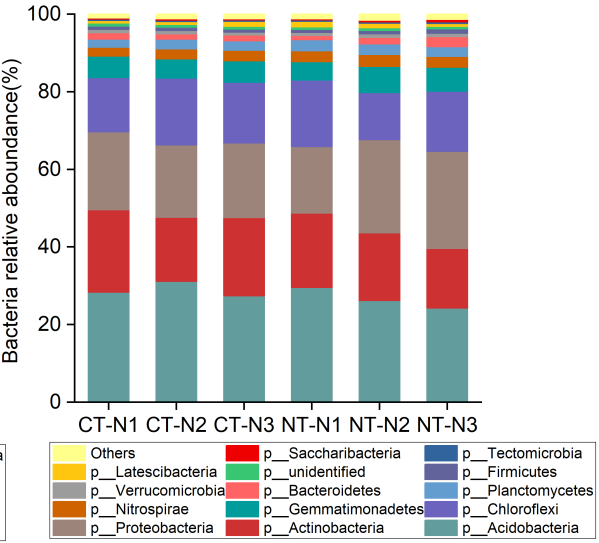

(d) Fungi relative aboundance $10-25 \mathrm{~cm}$

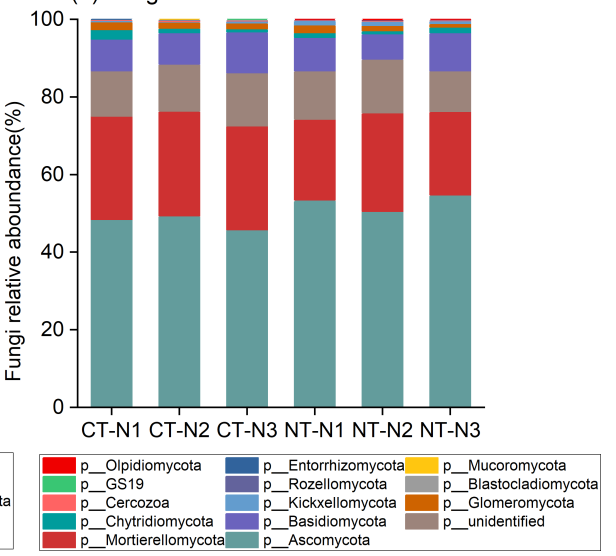



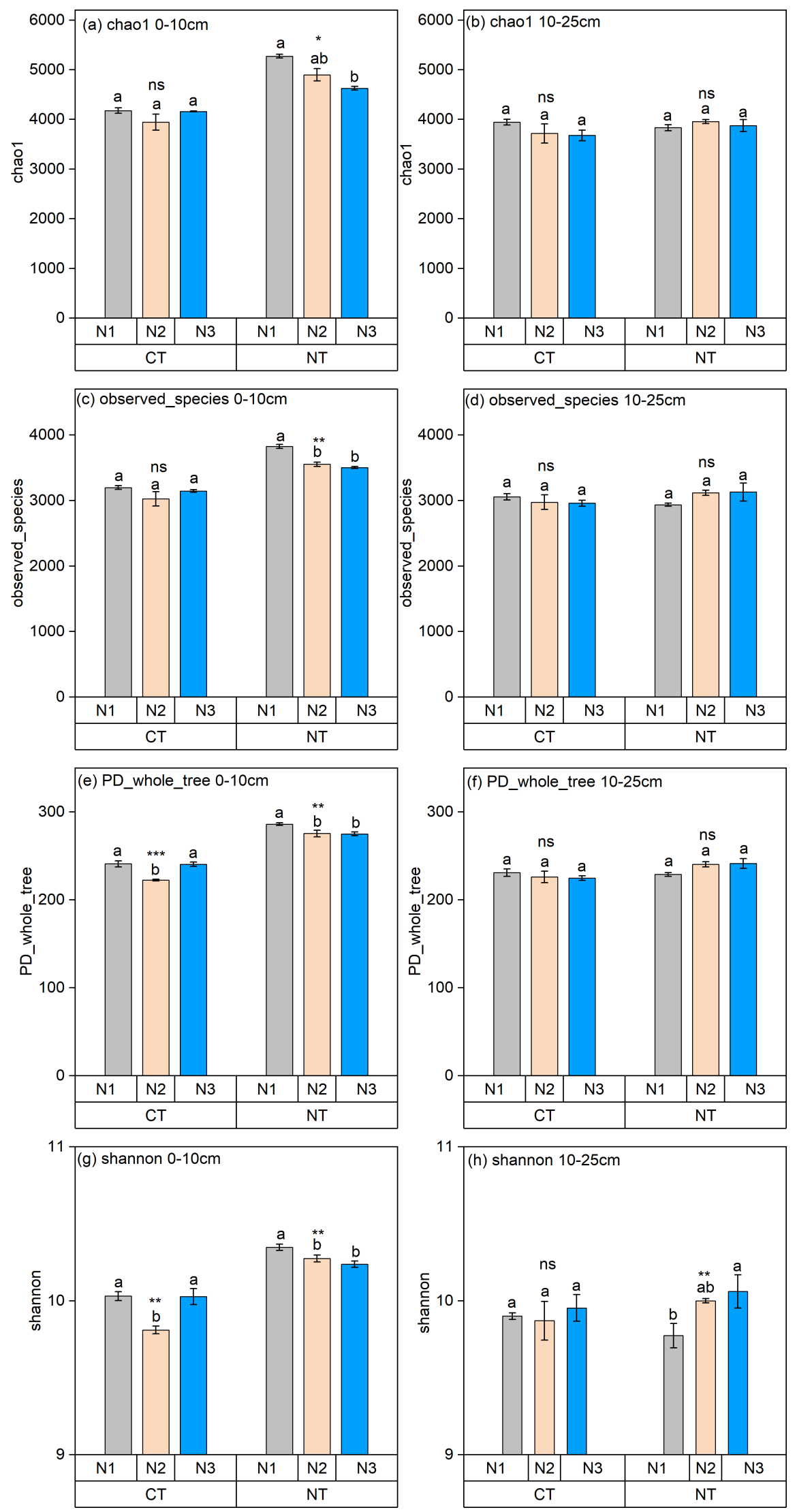

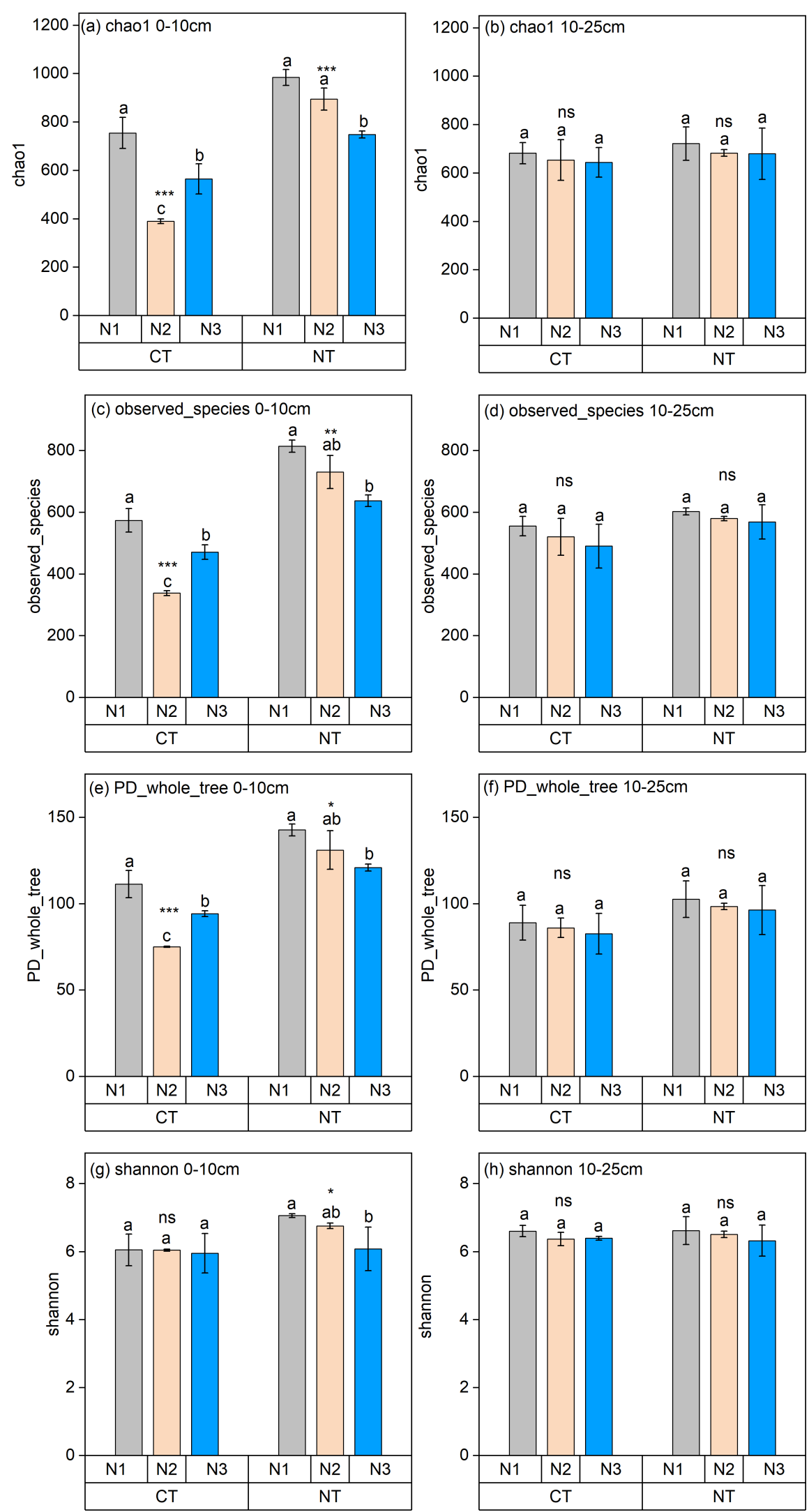

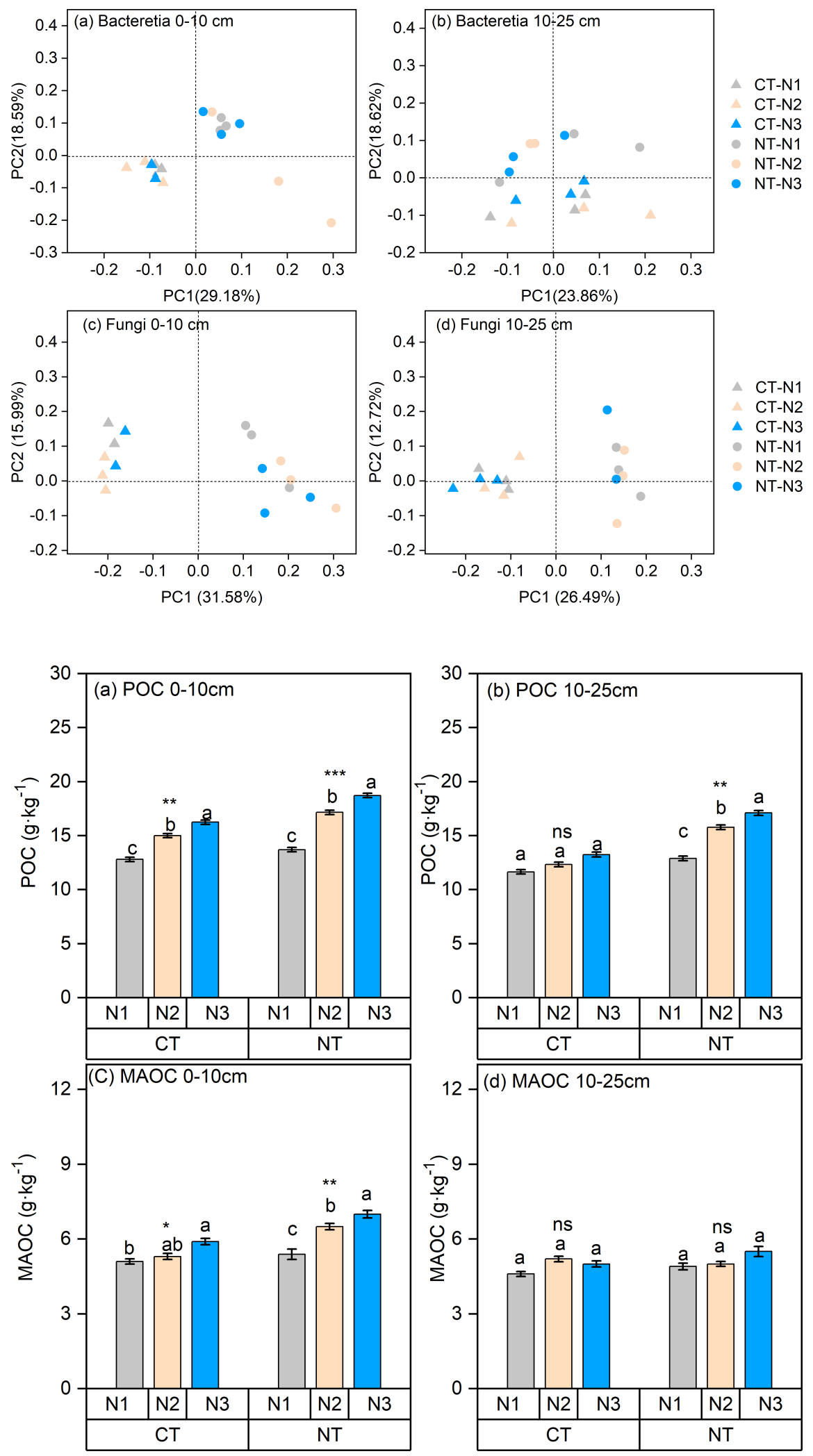


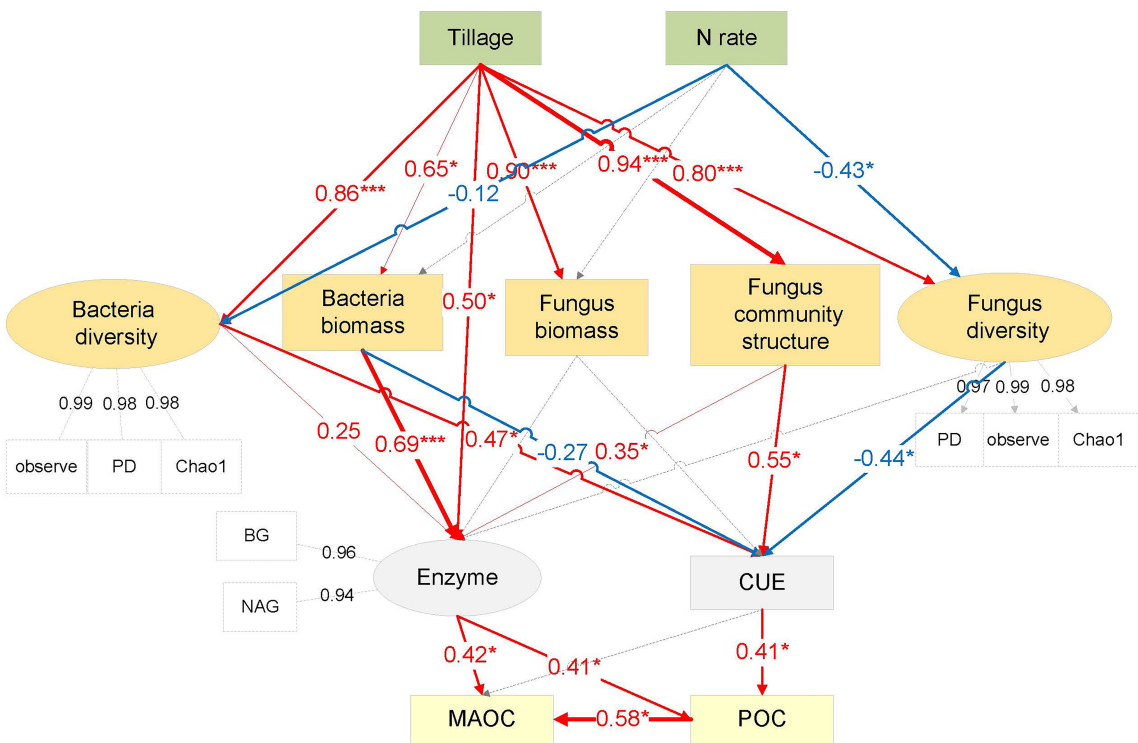

